\title{
Local Wisdom of Indigenous Moronene in Shifting Cultivation System in Bombana District
}

\author{
Rekson Solo Limba ${ }^{1}$, Weka Widayati ${ }^{2}$, Taane La Ola ${ }^{3}$, Nasrudin Suyuti ${ }^{4}$ \\ ${ }^{1}$ Faculty of social and political sciences, Halu Oleo University, Indonesia \\ ${ }^{2}$ Faculty of Earth Science and Technology, Halu Oleo University, Indonesia \\ ${ }^{3}$ Faculty of Agriculture, Halu Oleo University, Indonesia \\ ${ }^{4}$ Faculty of Cultural Studies, Halu Oleo University, Indonesia
}

\begin{abstract}
Moronene is one of the "indigenous people" in Southeast Sulawesi which has an "agricultural culture" with the cultivation system based on "local wisdom". This community is expert in managing primary forests to cultivated land by any type of rice plant were carried out according to local wisdom systems with various rituals (Storm 1925). Moronene has a variety of traditional knowledge associated with the "shifting cultivation system". This local knowledge an identity of indigenous Moronene actualized in the "customary marriage", which requires the existence of customary paraphernalia in the form of agricultural tools, such as; axes, machetes and spears. These three tools were symbols of the main livelihood of Moronene ancestors in ancient times and are still preserved until now. One of the efforts to preserve cultural values is performed by the customary paraphernalia called "langa" during the traditional ritual of marriage of the Moronene. The philosophical meaning of "langa" is the agricultural tools to symbolize that the husband and wife must be ready and be able to use the tools to meets the needs of family life. The principal issue of this paper is "how the processes and the stages of shifting cultivation system based on local wisdom in indigenous Moronene (Indigenous Peoples Moronene - MAM). The purpose of this article is: (1) "to describe and analyze the processes and stages of shifting cultivation system carried out by "Community of Indigenous Moronene" (MAM), (2) to describe the relationship between agricultural culture and the "customary marriage of Moronene". The method used is descriptive qualitative through observation, in-depth interviews (in-depth interview) of Focus Group Discussion (FGD), and documentation. It found that the indigenous Moronene might not be separated from the agriculture system. This has been hereditary merged and become an identity of Moronene. Therefore, customary of "langa" is a symbol, and an identity of the Moronene who still upholds the values of local wisdom, particularly in the management and utilization of natural resources (forest).
\end{abstract}

Keywords: Local wisdom, Indigenous Moronene Community, Shifting Cultivation

\section{Introduction}

Moronene is one of the indigenous people in Southeast Sulawesi, Indonesia, who have a variety of local cultures which have not been published widely; therefore, it is interesting to be explored in this paper. One of them is the culture of shifting cultivation system of the Moronene. This system has applied local wisdom values. In addition, it also has a philosophical meaning of life which is fundamental to the indigenous Moronene (MAM), which is embodied in the traditional symbols of marriage.

According to the tradition, a "culture of agriculture" has a relationship with the philosophy of "customary marriage" as one of the values of Moronene local wisdom. The customary marriage is a form of local wisdom, a unique identity and be used as guidance in social life. One of the uniqueness of the "Customary Marriage of Moronene" is its local wisdom which constitutes "a cultural symbol of the agriculture" an important element in the "customary marriage" called "langa". The term "langa" is a set of customary paraphernalia consisting of "white cloth, gloves, buffaloes, gongs, plates, kettles, pots, women's jewelry (necklace gold), machetes, axes, and spears." There are three types of equipment of the latter, it is a symbol of a "agricultural culture" which means people of Moronene are as farmers, should have agricultural tools symbolized by the last three of the tools.
This local wisdom is still alive and maintained by indigenous people. It is derived from the values, norms and ideas of the ancestors filled with wisdom and sense of justice, which is felt to be very important in regulating public order, so the regulations must be obeyed and followed in arranging the survival of future generations.

The practice of the local wisdom is characterized by a set of custom objects called "langa" as mentioned above, as a form of personification of a girl who will leave his parents. Thus, parents will be sincere and bless their daughter to be married by a man. Today, "langa" is considered pivotal to all Moronene communities as "customary law" that must be implemented all community members who want to organize "customary marriage". In short, the "langa" is very central because as an essential condition for the validity of the implementation of the customary rituals of the Moronene marriage.

Based on the description above, the problems of paper are (1) how are the process and stages of managing shifting cultivation systems based on local wisdom, and (2) what is the relationship of philosophical meaning between agricultural culture and the customary marriage of Moronene as a form of local wisdom in the reality of the Moronene daily lives. 


\section{International Journal of Science and Research (IJSR) \\ ISSN (Online): 2319-7064}

Index Copernicus Value (2013): 6.14 | Impact Factor (2014): 5.611

Therefore, the purpose of this paper is to: (1) describe and analyze the processes and stages of shifting cultivation management system based on local wisdom in "Indigenous Moronene People (MAM); (2) explore and analyze the relationship of philosophical meaning between the agricultural culture and the customary marriage of the Moronene.

\section{Literature Review}

\section{Local Wisdom}

The term local wisdom can be understood as ideas and local knowledge that is wise, full of wisdom, good value, and virtuous owned and guided, and carried out by members of the community. The study of wisdom has long been the subject of philosophical studies. Since the advent of the sophists approximately in the 5th century BC, who named themselves as wise men or wise people? At that time, the study of "wisdom" was very important to set the order of human life. In the court, the lawyer did not exist at that time then the wisdom (Sophia) is a tool that regulates social order (Sibarani, 2012).

The definition of local wisdom can be seen in two aspects namely; in the aspect of cultural values and the aspect of discretion in organizing the social life. In the first aspect, "local wisdom" is defined as native wisdom or knowledge of the noble values of cultural tradition to set the order of a society. While the local wisdom emphasizes the aspects of wisdom, defined as local cultural values that can be used to set the order of a society in a wise or prudent" (Sibarani, 2012).

Paryitno (2011) defines that local wisdom local wisdom is all forms of ideas that have local or local properties of thoughtful, full of wisdom, good value, which embedded and followed by members of the community. Likewise Keraf (2002), defines local wisdom is "all forms of knowledge, belief, understanding or insight, as well as customs, or ethical which guides human's behavior in life in ecological communities". In line with the definitions above, Marianne concludes that local wisdom is "the values prevailing in a society which is believed to be true and used as a reference and guide of local communities in their daily behave" (Mariane, 2014).

Moronene cultural phenomenon in relation to the process and stages of shifting cultivation system, is highly influenced by cultural values and religious belief systems adopted by the indigenous Moronene. Therefore, theoretically, the phenomenon can only be explained by cultural and religious theories.

\section{Cultural Theory}

In the system of cultural society, there are values espoused and applied into code of conduct called customs. These values have created traditional knowledge systems about natural phenomena and the environment for human beings. The traditional knowledge systems, then creates a trust for the presence of spirits (gods) who reside in the wilderness of life and serves to manage and control natural phenomena. Of such trust can raise collective consciousness for a certain group of people to be friendly and careful in managing natural resources (forest). The collective consciousness contains the values of "local wisdom" that led man to behave toward nature and natural resources.

Kluckhohn cited in Koentjaraningrat (2000) claims that the nature of human's relationship with the natural surroundings and the nature of human relationships with others is a starting point in explaining the phenomenon in this study. Human's relationship with nature is the basic theory (grand theory) to explain the wisdom of local communities to the conservation of forest resources; the emphasis is on the factor of "prudence" of human in forest management so as not to damage the ecosystem. Then, the human's relationship with his neighbor would explain the phenomenon of social relationships, either horizontally or vertically.

In human's relationship with nature, there is a cultural group that sees nature as a very powerful thing, so that people just give up, without much effort they can conquer or change the nature. In contrast, many other cultures that view nature as something that can be fought by humans, and requires them to always try to conquer nature. There are also other cultures that consider that human beings can only seek harmony with nature. In the cultural context of the latter, indigenous people conserve and utilize forest resources wisely and seek to maintain its sustainability, thus harmonizing the relationship of human and nature is maintained.

\section{Religious Theory}

According Koentjaraningrat (1980), initially, humans only use their knowledge to solve problems, but gradually their knowledge systems are more limited and even no longer able to solve problems. When the intellect is not capable, then it is often human solve the problem through magic, or witchcraft. Magic is all human action to achieve something by using the forces of nature and beyond. However, in the subsequent development of the magic power is not always successful. Since then human began to realize that here are delicate creatures inhibit the nature. And then, human began to seek relationship to these delicate creatures. In an atmosphere of helplessness of the human psyche, he later resigned, and at the time there was a religion. Religion is any system of human behavior to receive something through surrender to the creator.

In relation to the shifting cultivation system of the Moronene, there are several theories that support this study. These theories include the theory of animism, supreme deity theory, theory of incredible power, and the theory of animism and sprites.

\section{Animism theory}

According Taylor (1873), Animism is a belief in the existence of spirits and the spirits that inhabit the whole universe. This theory is meant as an attempt to find the origin and development of religion in human culture. It is seen as the origin of religion of human's consciousness of the soul and spirit (Hadiwijono, 1985). In addition, Subagya maintains that animism in its broadest sense is meant each of spiritual elements (anima-soul, life, spirit, etc.) in the element 


\section{International Journal of Science and Research (IJSR) \\ ISSN (Online): 2319-7064}

Index Copernicus Value (2013): 6.14 | Impact Factor (2014): 5.611

of physical, either inside or outside human. In more specific sense animism shows belief in spirits that stands apart from the human and which interfere in human affairs. The fact the beliefs of those spirits would not justify the theory of animism of Tylor and his colleagues, that all religions are of the belief that evolution (Subagya, 1981).

\section{Supreme deity theory}

According to Lang (1898) that is based on fairy tales and myths tribes Murba, Lang argues that there may be parts Murba looked to the gods as spirits, as proposed in the theory of animism Tylor. In terms of tales and myths, Lang came to the conclusion that "the Murba believed in the existence of a god figure that is seen as a figure of the supreme god of "Supreme Being, High Good" (Hadiwjono, 1985).

\section{Incredible power theory}

The theory of the incredible power of Marett (1909) is a criticism of Tylor's theory which confirms that the origin of human religion is 'the base of religion', which is an emotion or a thrill that arises due to the admiration of human towards things and specific symptoms that are outstanding. Nature in which things as well as the symptoms are coming from, the human regarded as the world, where there is a variety of incredible power. That is, the power of which cannot be explained by ordinary human, namely the power of the supernatural. In Indonesian, the incredible power can be called magical powers or magic powers, while the world where supernatural forces come from so-called occult or supernatural world (Koentjaraningrat, 1985).

\section{The theory of Animism and Spiritism}

Kruyt (1906) developed a theory about the shape of an ancient human religion centered on the supernatural power of Codrington and Marett. Kruyt's theory states that "human of ancient times were generally convinced that there was a smooth substance that gives the power of life and motion to a lot of things in the universe". The subtle substance by Kruyt called "zielestop" contained in the human body, animals and plants, and often also on the body. Human body parts that contain more "zielestop" than the other is the head, hair, nail, offal, dental center, saliva, sweat, tears, urine, and feces. One can also add "his zielestop" by taking certain substances, for example, blood. Belief in "zielestop", Kruyt calls it as "animism".

Based on the understanding of local wisdom and the concept of culture and religion above, then the local wisdom in this context can be summed up as part of the "culture", where after going through a series of processes "appreciation", then created a traditional knowledge system for the local community. Traditional knowledge systems that are believed to contain the truth have become a reference in society to behave and act, so that these beliefs affect the values of local wisdom to the conservation of forest resources. To explain the process of the emergence of local wisdom can be described as the following diagram.

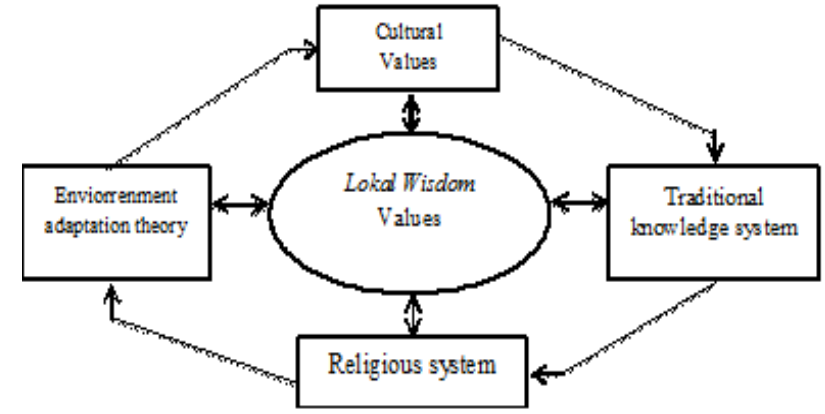

Figure 1: The process of local wisdom

The relationship between local wisdom as a pattern of behavior of society towards forest management belief in gods (spirits) can be explained by the theory of religion, that people believe that the saint was there, and are beyond the capability and power, because the human requires God's protection by keeping natural balancing through various ceremonies. The term religion indicates a relationship between humans and supernatural powers.

\section{Research Method}

This paper is based on a case study with a qualitative approach in kampong Hukaeea-Laeea, Bombana. This study applied a qualitative approach in attempting to maintain (to preserve) the form and content of human behavior to analyze quality of the data. In this case is the behavior of indigenous people in kampong Huka'ea - La'ea (study sites). To answer the problem of this study, both primary and secondary data were used. The primary data were obtained through field work methods which included participant observation, indepth interviews, and FGD (Focus Group Discussion) techniques. The secondary data were obtained through documentation technique.

To have a better understanding on the real situation and conditions in the field site, the main instrument used in this study was "human" (Moleong, 1994). With the human instrument, it can be more easily to make changes or adjustment when required. This study used descriptive analysis techniques through the stages of interactive analysis technique that consists of three flow activities happening simultaneously, namely data reduction, data presentation and conclusion/verification (Miles and Huberman, 1992).

\section{Results and Discussion}

\section{Steps in shifting cultivation system}

This study has found 11 steps in shifting cultivation system of Kampong Hakaea, they are; (1) Mo"oonto Wita; (2) Umowu, (3) Monea, (4) Humuni, (5) Modahai, (6) Mewala, (7) Motasu, (8) Morobusi, (9) Montoria, (10) Mongkotu, and (11) Mewuwusoi. Each step of these will be discussed as follows:

1) Mo'oonto Wita (Selection of shifting cultivation area) At this stage, based on the agricultural calendar (traditional), the peasants will work together to find a fertilize land forests for shifting cultivation purpose. These activities are usually guided by someone who has traditional knowledge of faulty 


\section{International Journal of Science and Research (IJSR) \\ ISSN (Online): 2319-7064 \\ Index Copernicus Value (2013): 6.14 | Impact Factor (2014): 5.611}

particularly regarding natural character, both physical and non-physical soil fertility associated with the guardian spirits of nature which is called "Nteiwonua".

In these activities, there are some rituals are performed as a form of local wisdom, namely; mebilangari/kalapuaro, mekilala, mo'ooli, and mobelai wita. Mebilangari Kalapuaro. These are ways of obtaining a natural gesture to know about all things associated with good luck, safety and vice versa. According to Storm (1925) cited in Limba, et al, (2014), bilangari is a local wisdom (local genius) of the Moronene associated with selection of a good time to perform certain activities.

The bilangari ritual is done traditionally by using a container or a medium made of plank-sized $(7.5 \times 5 \mathrm{~cm})$ as Figure 2 below.

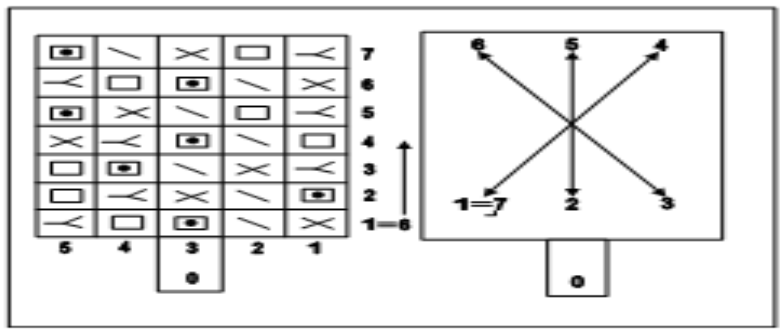

Figure 1: Kalapuaro Boand "Bilangari'

The original container of bilangari made of buffalo bone carved temples/written with symbols without numbers like the above, because the meaning is only known by the bilangari expert. Numbers 1 through 6 was made after a number of people who can read and write to learn bilangari /kalapuaro. Mekilala is telling fortune as a way to get something natural gesture in predicting what will happen in two indicators called "moniu" and "mobui". Moniu is a term that is showing signs of good, otherwise mobui shows signs are not good.

According to Storm, (1925) cited in the Limba et al, (2014), the term kilala, is a local wisdom that serves as a tool to get hints about natural signs. As with bilangari, kilala also is the local wisdom systems related to aspects of safety signs, health and luck, especially for those who are in danger. In relation to the selection of land for cultivation, the ritual mekilala made after farmers received forest areas that are considered good, and then the ritual demand signs to the supernatural manner called "mekilala".

Mo"ooli is a ritual of "purchasing or redeeming" which performed symbolically as a customary request for permission to establish agricultural land in the region. The ritual mo'ooli is often performed by a traditional leader called "pembue'a" who is believed to have ties spirits called „Nteiwonuace.

The mo"ooli ritual using ingredients of offerings that consists of sarongs, trousers and shirts, as well as materials for cigarettes, tobacco and betel nut which are stored in a chamfer (nyiru), and placed on loft (para-para) and then the traditional leader perform rituals with read incantations which intends to invite all the inhabitants of the forest area of the four directions (north, south, east and west) to come take their share of the offerings that have been provided. It is believed that by doing this ritual, all forest creatures will move to other forest areas and will not bother the farmers who will occupy that area.

Mobelai wita is a traditional ritual performed symbolically to start agricultural activities in the region. According Rambe (2002), how mobelai wita prevailing in Rumbia and Poleang are as follows. Firstly, make a small peg along $+30 \mathrm{~cm}$, then driven into the ground as deep as $10 \mathrm{~cm}+$. Plugging this peg is "mobelai wita" (wounding land) undertaken symbolically. Secondly, the remaining $20 \mathrm{~cm}$ fenced round with three small wooden rod as high as $+40 \mathrm{~cm}$, at the end of the third tied together so as not easily collapse. Once this is done, thirdly, immediately followed by clearing around the triangular peg earlier, measuring $+5 \mathrm{~m}$ circumference mark the beginning of forest clearing fields.

\section{2) Umowu (logging small trees, roots, and weeds)}

The term "umowu", is the initial phase of core farming activities, deforestation is the first stage by clearing small trees, roots and weeds crept under large trees. Umowu is intended to facilitate further work when logging large trees called "Monea".

In the implementation of agricultural cultivation activities, the tradition of mutual assistance carried out by the peasants with rotating (meliuha) from one land owner to another land owner. There are certain stages in the fields that can be done. For example, at the stage of umowu, monea, and other works require more field workers.

\section{3) Monea (cutting down trees)}

Monea means cutting down trees ranging from small to large stands. In the context of cultivation, monea is the second phase of activities, namely logging large trees thoroughly. Monea activities were held in mutual cooperation by rotating (meliuha) which is generally done by men. Generally, the equipment used is a hatchet, machete, and a whetstone (pali, ta'owu, and po'ahara), as mentioned in the custom of langa prviously.

After logging, then while waiting stage of drying land for about 1-2 months, farmers do cleaning the field boundaries of sticks, twigs and dried leaves as wide as 3-5 meters, called meheasi/mekere. This meant that at the time of burning woods (humuni), the flames do not spread to the forest to a core that is outside the cultivation areas.

\section{4) Humuni (burning woods)}

The term humuni is derived from Moronene word ,hunio "e or „tunuo", meaning "burn". So, humuni is burning activity (burning) of forest areas that have been cut down. These activities conducted after all logging in the region is dry, so it can produce good combustion, ie all branches, branch and leaves completely charred. The result of perfect combustion will facilitate further work.

A safe way of humuni is against the direction of the wind at the area of combustion. For example, if the wind is blowing 


\section{International Journal of Science and Research (IJSR) \\ ISSN (Online): 2319-7064}

Index Copernicus Value (2013): 6.14 | Impact Factor (2014): 5.611

from the East to the West, then the trigger must fire from the West. If the wind is blowing from the North then triggers a fire must be from the South. It is intended to fire against the wind so it does not spread out the cultivation areas.

\section{5) Modahai (Track, Rob and Burn)}

Modahai is follow-up activiy after humuni, just before the planting activities. Modahai means cutting branches and twigs as combustion residue. The large stem of the wooden rod left on its place, while the branches were not burned gathered for fencing materials (mewala). Generally, the modahai is done by adult men and women on their own land farms. There are two activities while waiting for the planting season, namely: (a) Wungkali is cutting, weeding and urning activities; (b) Mewala is putting a fence (usually a haw), but if the cultivated fields side by side with other neighbors, the fencing can be done collectively - together with the neighboring fields, so that the fencing work more easily and quickly done.

\section{6) Mombula puhu (planting corn)}

Before growing season, each farmer has to provide a large selected corn seeds which have been picked from the cob and stored in containers called ,balase ${ }^{\text {ee }}$, is, a type of woven bags of leaves agel. Corn planting is carried out by men and women with meliuha system (a rotating mutual cooperation). As for the materials and equipment required are: (a) the selection of corn seeds to be planted, usually ordinary corn and sticky corn. The numbers of seeds are prepared in accordance with the size of cultivated land; (b) balase on small size approximately contains 1 liter of seed corn to be held by each sowing seed. The number is adjusted by the amount of people who will sow the seeds; (c) potash, the drill tool made of hard wood with a diameter of $\pm 5 \mathrm{~cm}$, shoulder height of adults. At the one end is sharpen then burned to make it more resistant to the hard ground; (d) the corn planting is done prior to 14 days before rice planting (motasu). In other words, after the corn grows leaves the position of the three strands touching the ground, then the cropping immediately implemented.

Then the next stage in the corn planting is a stage called "mepuhu" (corn harvest). When the corn is unbiased and old, it will soon be harvested. To determine the age of the corn already to be harvested, the sign is when the corn skin has dried. In such conditions, the corn crop to be harvested soon and implemented with the wage system of work, adjusted with the harvest products.

\section{7) Motasu (planting rice)}

Motasu is planting or sowing rice. It is conivityducted in a way to help each other or "mutual cooperation by rotating" called "meliuha". The division of labor in motasu consists also on a group of men as the creator of the hole on a field and women's groups as sowing rice seeds, just like planting corn as discussed previously. The tools used are also the same, namely potasu (a stick of hard wood which is sharpen on the edge to make a hole), and balase (bags woven from leaves agel) to store about one liter filled seeds. The bag is a special bag for both rice seeds and corn seeds).
According to the Moronene tradition, a good planting season is to follow the agricultural calendar system that is based on the position of the stars in the sky. According Rambe (2002), there are natural signs that are used as a good guide for planting season, among others; (1) when the leaves of the trees have started to grow (change) young leaves called tumiri. It is a sign that the rainy season is about to come, (2) when it appears three-star line up, called "tina'o" the light is brighter than other stars, and (3) when the rise of the seven so-called "molunu", which glowing light. Such signs are used as local knowledge of Moronene farmers to decide a good time to plant rice.

\section{8) Morobusi (weeding)}

Morobusi is a time for weeding rice and corn grass and weeds that interfere the growth rate of plant fertility. This activity is also done in mutual cooperation innings), but usually, more often done by the owner of the field alone with the family members.

\section{9) Montoria (keeping birds)}

The term montoria is an activity done one step ahead before harvest season undertaken. Montoria means to preserve and maintain the plant. In essence, it is the work of farmers which requires more energy especially at night, because they cannot sleep. If a fence or wala done with a strong construction and tidy, would be very helpful, because pigs cannot enter. But if the fence is not strong enough, the agricultural products are seriously threatened. Therefore, the fence will determine the success of a cultivated plant.

\section{0)Mongkotu (harvesting rice)}

The term "mongkotu" is also called "mosowi", which is cutting paddy in the rice fields with "ani-ani" (cutter) called "pongkotu". The mongkotu is only done at harvest time. Mongkotu is the most important phases for every farmer. Prior to the harvesting season, the owner of the rice field prepare everything required for harvesting. The rice field owner reports that the paddy has yellowed and ready to be harvested. At that time the rice field owner requested willingness of Tompuroo (rice shaman) to guide the mongkotu, ranging from mobelai pae done the day before harvesting time up to completion of mewuwusoi (year-end party). After that, the rice field owner will notify his relatives and other farmers to come together to cut paddy in his fields.

According to the Moronene tradition, mongkotu should be guided by someone called Tompuroo, is a "rice shaman" who is good in communication between "rice spirit", and"sangkoleo mpae" (rice god). Rice shaman is a man who understands ritual manners, as well as establishes requirements and materials ritual that must be prepared, as well as understands the taboo act that should be obeyed by all farmers during the harvest season. Before harvesting on a certain rice field, Tompuroo will first perform the ritual of cutting paddy symbolically called mobelai pae by cutting paddy with ani-ani seven stalks of the paddy that are in the vicinity, and tied with the paddy leaf and then stored in "medicine basket" called komperoo belongs to Tompuroo.

After the ritual, then Tompuroo will issue a signal that the harvest has been able to start together on that day called

\section{Volume 5 Issue 3, March 2016}




\section{International Journal of Science and Research (IJSR) \\ ISSN (Online): 2319-7064 \\ Index Copernicus Value (2013): 6.14 | Impact Factor (2014): 5.611}

"olinco morapo". In general, any participant use their own crop tool of ani-ani (pongkotu), but also sometimes it is provided by the owner of the rice field. Yields are measured in the number of "bunches of rice" ranging from the smallest to the biggest unit called: kungku asa, asa Koo, asa kuro, asa lai, asa howu, as indicated in the following table:

Table 1: Measurement

\begin{tabular}{|c|c|}
\hline Local measurement & Volume \\
\hline Asa kungku & 1 handful of rice \\
Asa koo & 4 handful of rice \\
Asa kuro & 12 bunch of rice \\
Asa lai & 24 bunch of rice \\
Asa howu & 48 bunch of rice \\
\hline
\end{tabular}

Finally, when the Tompuroo all completed, then the communities immediately prepared feasts end of the harvest, called "mewuwusoi".

\begin{abstract}
11)Mewuwusoi "(Annual harvest feast)
"Mewuwusoi" is a ritual performed by a group of famer led by community leader called Tompuroo at the end of the harvest season. Therefore, mewuwusoi event was a "late season rice harvest festival", organized with joy by all communities who are affiliated with the Tompuroo (shaman rice), which is carried out at the house of Tompuroo or other house by agreement.
\end{abstract}

According to Rambe (2002:255), mewuwusoi is aceremony of purification or ablution any errors or violations that may have been committed against what is forbidden (upali) during the harvest season (wulangkotua). The aim is, that all members of the farmers to remain healthy, it can work again on their farm in the following year and gained fruitful.

\section{Customary relation (local wisdom) and agricultural culture}

One of the uniqueness of indigenous Moronene is its customary marriage system that is empirically proved to have a connection with the philosophy of a "agricultural culture". Therefore, it will be explained the relationship between the "agricultural culture" and "customary marriage of Moronene", in which both of these have a fundamental philosophical meaning because the two are inseparable.

In Moronene culture, farming tradition is one of the main livelihoods for the family to meet the needs of economic life. While "marriage tradition" is means to deliver the transitional status of single to married.

The relationship between the agricultural culture and customary marriage has philosophical meaning that is to go through matrimony; a young Moronene must carry out customary marriage. In the customary marriage of Moronene, there is a provision called "langa" which symbolize agricultural culture. In terms of the material, langa consists of a set of "customary objects" which becomes obligation for parents (father/mother/guardian) to the prospective groom to be offered to the parents (father/ mother/guardian) of the bride during the process of customary marriage taking place.
The langa consists of some elements such as: livestock, white cloth, household tools, furniture, women's jewelry, and agricultural tools such as; machetes, axes, and spears. The last three tools are symbols that represent the culture of agriculture. By having these agricultural symbols in the customary marriage of Moronene indicates how important agricultural culture in the philosophical lives of the Moronene. In addition, the essence of langa in the philosophical view of family life is that, "langa" essentially means "personification" called "lilino wotolu" of a girl which would leave the house of her parents because she has to follow her husband.

The relationship between customary marriage and agricultural culture in this paper can be explained from the aspect of the meaning of "responsibility of husband and wife" in a household life. In Moronene custom, there is a principle of a householder's life called "mesinca", that is on separation of the nuclear family after married. Once someone is married, then he himself has been responsible for meeting the obligations of the socio-economic needs of his own household. To undergo this responsibility, then machetes, axes, and spears required in the customary marriage imply that every person who has been married in Moronene custom, he is immediately associated with the "world of agriculture". Thais means that he should use agricultural tools symbolized by objects of "machetes, axes, and spears", as defined as "langa" in customary marriage of Moronene.

\section{Conclusion}

It can be concluded that the indigenous Moronene, in the research area is native ethnic group in which according to the oral tradition (or folklore); Moronene is the oldest ethnic group that first arrive in the mainland of Southeast Sulawesi. This ethnic group is known as a community that has the expertise in agriculture. Only by using simple traditional tools such as machetes and axes, they are able to open up wilderness areas to be used as agricultural fields planted with the main types of rice and corn crops as well as the substitution of other crops.

As the main livelihood, shifting cultivation systems is an identity of the indigenous Moronene which has many symbols of socio-cultural life and daily life system in the community. One indicator of the agricultural system done professionally by Moronene community, is seen from the ways of the implementation process of the shifting cultivation activities undertaken by 11 (eleven) stages as described above.

In addition, the agricultural culture of Moronene has a very basic philosophical meaning in the process of the Moronene from one generation to the next. Due to the significance importance of agricultural culture in the philosophy of Moronene communities, the langa is established a set of customary objects as a personification or self-replacement of a girl who would leave the house and parents after marriage. A set of customary objects is related to agricultural culture, such as machete and axes as symbol of agricultural communities of the Moronene. 


\section{References}

[1] Hadiwijono, Harun (1985) Religion of the Murba in Indonesia. BPK Gunung Mulia, Jakarta

[2] Koentjaraningrat. (2000) Culture, Metaliteit and Development, Jakarta: Penerbit PT Gramedia.

[3] Kruyt, A.C. (1906). Het Animisme in den Indischen Archipel (Animism in Indonesia).

[4] Lang, Andrew (1898). The Making of Religion

[5] Lang, Andrew (1901). Magic and Religion

[6] Limba, Rekson Solo, dan Abdullah Muhammad Samir (1995) Review on Customary Marriage of Moronene in Taubonto-A guide Book), Hasil Musyawarah Adat Moronene 23 Juli 1995. Unpublished.

[7] Limba, Rekson Solo (2015). History of Motonene, Lukita, Yogyakarta.

[8] Mariane, Irene (2014). Local Wisdom of Customary Forest Management. PT. Raja Grapindo Persada, Jakarta.

[9] Rambe, (2002) Culture of Moronene: various ritual on livelihood, geographical view, historical and anthropological prespectives,

[10] Subagya, Rachmat (1981). Original religion of Indonesia. Sinar Harapan dan Yayasan Cipta Loka Caraka. Jakarta

[11] Sibarani, Robert, 2012. Local wisdom: the nature, role and method in oral tradition. Asosiasi Tradisi Lisan (ATL), Jakarta

[12] Storm, Br.G. (1925) Discourse of Planting Paddy by the Moronene in Rumbia, KILTV, Leiden

[13] Tylor, E.B (1873) Primitive Culture. 